\title{
Sea Surface Temperature Measurment from Space Allowing for the Effect of the Stratospheric Aerosols
}

\author{
by
}

\author{
T. Takashima and Y. Takayama
}

Meteorological Research Institute, Tsukuba, Ibaraki 305, Japan

(Received Feb. 2, 1986 ; Revised April 25, 1986)

\begin{abstract}
A method of deriving the sea surface temperature (SST) from space is described by using the infrared channels of NOAA-AVHRR radiometer with reference to a model atmosphereocean system. It was found that when free of stratospheric aerosols the combined use of channels $3(3.7 \mu \mathrm{m}), 4(11 \mu \mathrm{m})$ and $5(12 \mu \mathrm{m})$ is effective for the SST derivation for a moderate amount of precipitable water. However, in the case of a large amount of water vapor, its vertical profile has to be simultaneously determined to correct the water vapor effect. Furthermore, to evaluate the effect of the stratospheric aerosols on SST, the visible channels are also utilized for the atmospheric correction, where the radiation from the atmosphere is affected more by the presence of stratospheric aerosols.
\end{abstract}

\section{Introduction}

In deriving the sea surface temperature (SST) from space, the atmospheric correction is one of the major problems to be solved. There before to improve the accuracy of SST, the atmospheric condition has to be simultaneously investigated. In this respect, the various combinations of multi-channels provided by the Advanced Very High Resolution Radiometer (AVHRR) on borad the NOAA-satellite tend to be untilized with the aid of the atmospheric transmittance models. The AVHRR on the NOAA-7 detects the emitted radiation in the IR window channels $3.55-3.93 \mu \mathrm{m}$ (ch. 3), 10.5-11.5 $\mu \mathrm{m}$ (ch. 4) and 11.5-12.5 $\mu \mathrm{m}$ (ch. 5), together with the reflected radiation in the visible window channels, 0.58-0.68 $\mu \mathrm{m}$ (ch. 1) and 0.725-1.10 $\mu \mathrm{m}$ (ch. 2) with the spacial resolution of $1 \mathrm{~km}$ at the sub-satellite point.

In the wavelength region ranging from 10.5 to $12.5 \mu \mathrm{m}$, the atmosphere is relatively transparent, and is therefore suitable for determining SST. However SST measured by satellites is usually lower than the real ocean surface temperature, which is estimated to be from 4 to
$8 \mathrm{~K}$ in the tropics (Prabhakara et al., 1984). This is mainly due to the absorption by the atmospheric water vapor. The correction of absorption by water vapor was undertaken by the split window mersurement technique (10.5$11.5 \mu \mathrm{m}$ and $11.5-12.5 \mu \mathrm{m})$ by the abovementioned authors. Unfortunately this method is limited only to the atmosphere with a moderate amount of water vapor. In the region ranging from 3.5 to $4.0 \mu \mathrm{m}$, the effect of water vapor, appears to be less than in the $11 \mu \mathrm{m}$ window region. However, besides water vapor, the effect of uniformly mixed gases and aerosols upon SST becomes significant. In addition, the effect of the ocean-surface emissivity should also be investigated for the purpose of further improvement. In the daytime, the temperature deviation is quite large, particularly in the sunglint due to the solar radiation directly reflected by the surface. Therefore this region has so far been limited to utilizing the night data only.

The volcanic eruption of E1 Chichon on April, 1982, has resulted in a marked effect on radiative transfer in the atmosphere, where the - 
radiative properties of the stratospheric aerosols by the eruption was discussed by King et al. (1984). Hofmann and Rosen (1983) pointed out that the aerosols are composed of a $75 \% \mathrm{H}_{2}$ $\mathrm{SO}_{4}$ aqueous solution with recent balloon-borne boiling point measurements. This eruption has also had a marked effect on the SST retrieval from space. The satellite derived SST exceeded $-2 \mathrm{~K}$ bias right after the eruption. This error continued throughout the winter, 1982 1983, and began to decrease in the spring, 1983 (Strong et al., 1983). Thus the enhancement of the stratospheric aerosols has resulted in making the atmospheric correction on SST more difficult. In this paper the effects of such atmospheric constituents as water vapor and aerosols are investigated to derive SST by the use of the multi-spectral AVHRR in the daytime and night orbits.

\section{Method}

To derive SST, first of all, a model atmosphere bounded by the ocean surface was considered as a reference. The optical thicknesses of the various constituents in the atmosphere are calculated on the basis of the temperature profiles provided by Selby et al. (1978). The vertical profile of water vapor was modified in such a way that the water vapor concentration is less in the middle troposphere and is more near the ocean surface in comparison with the LOWTRAN-4 data. The precipitable water is $3.24 \mathrm{gr} / \mathrm{cm}^{2}$ and $0.856 \mathrm{gr} /$ $\mathrm{cm}^{2}$ for $\mathrm{S}$ and $\mathrm{W}$, respectively. Table 1 shows the optical thicknesses of the major atmospheric constituents in mid-latitudes in summer (S) and winter (W) in the AVHRR channels. Among them, the effet of water vapor upon SST is the most important. Unfortunately this changes in time and space. To investigate this effect, four vertical profiles of the modified water vapor concentration were considered in mid-latitudes in summer and in winter (Fig. 1). The precipitable water is $2.42,3.24,4.34$ and $5.81 \mathrm{gr} / \mathrm{cm}^{2}$ respectively in summer, whereas it is $0.70,0.86,1.06$ and $1.30 \mathrm{gr} / \mathrm{cm}^{2}$ in winter. The model of the tropospheric aerosols was defined by McClatchey et al. (1972), where the aerosols are assumed to be spherical with the refractive index of water (Hale and Querry, 1973). The visibility of the atmosphere is $23 \mathrm{~km}$ (clear) and $5 \mathrm{~km}$ (hazy), respectively. As for the stratospheric aerosols injected by $\mathrm{E} 1 \mathrm{Chichon}$, the refractive index is assumed to be that of a $75 \%$ $\mathrm{H}_{2} \mathrm{SO}_{4}$ aqueous solution (Palmer and Williams, 1975), whereas the size distribution is assumed to be Deirmendjian model H(1969), since there is very little information available on the distribution. The optical thickness is normalized to 0.1 and 0.3 at $0.55 \mu \mathrm{m}$ in the present work. The underlying ocean surface was simulated by many facets whose slopes change with surface wind according to the isotropic Gaussian distribution with respect to surface wind (Cox and Munk, 1955), where the surface wind was assumed to be $5 \mathrm{~m} / \mathrm{sec}$.

Table 1. Optical thicknesses of the atmospheric constituents in mid-latitudes in summer (S) and in winter(W). Optical thickness of the stratospheric aerosols is assumed to be 0.1 at $0.55 \mu \mathrm{m}$. Precipitable water is 3.24 and $0.856 \mathrm{gr} / \mathrm{cm}^{2}$ in S and W, respectively.

\begin{tabular}{|c|c|c|c|c|c|c|c|c|c|c|c|}
\hline \multirow{2}{*}{\multicolumn{2}{|c|}{$\begin{array}{l}\text { atmospheric } \\
\text { constituents }\end{array}$}} & \multicolumn{2}{|c|}{ ch. 1} & \multicolumn{2}{|c|}{ ch. 2} & \multicolumn{2}{|c|}{ ch. 3} & \multicolumn{2}{|c|}{ ch. 4} & \multicolumn{2}{|c|}{ ch. 5} \\
\hline & & $s$ & $\mathrm{w}$ & $s$ & $\mathrm{~W}$ & $\mathrm{~s}$ & $\mathrm{~W}$ & $\mathrm{~s}$ & $\mathrm{w}$ & s & $\mathrm{w}$ \\
\hline \multirow{2}{*}{\multicolumn{2}{|c|}{$\begin{array}{l}\text { water vapor (line) } \\
\text { (continuum) }\end{array}$}} & 0.0 & 0.0 & 0.1540 & 0.0737 & 0.1348 & 0.0634 & 0.0600 & 0.0250 & 0.1121 & 0.0515 \\
\hline & & 0.0 & 0.0 & 0.0 & 0.0 & 0.0064 & 0.0007 & 0.4369 & 0.0452 & 0.6469 & 0.0670 \\
\hline \multirow{4}{*}{\multicolumn{2}{|c|}{$\begin{array}{l}\text { uniformly mixed gases } \\
\text { ozone } \\
\mathrm{N}_{2} \\
\text { molecule }\end{array}$}} & 0.0 & 0.0 & 0.0224 & 0.0227 & 0.0238 & 0.0242 & 0.0184 & 0.0187 & 0.0040 & 0.0042 \\
\hline & & 0.0286 & 0.0355 & 0.0009 & 0.0011 & 0.0006 & 0.0007 & 0.0036 & 0.0044 & 0.0000 & 0.0000 \\
\hline & & 0.0 & 0.0 & 0.0 & 0.0 & 0.0127 & 0.0132 & 0.0 & 0.0 & 0.0 & 0.0 \\
\hline & & 0.0602 & 0.0603 & 0.0197 & 0.0198 & 0.0 & 0.0 & 0.0 & 0.0 & 0.0 & 0.0 \\
\hline \multirow{3}{*}{ aerosols } & tropo-(clear) & \multirow{3}{*}{\multicolumn{2}{|c|}{$\begin{array}{l}0.1549 \\
0.5406 \\
0.1035\end{array}$}} & \multirow{3}{*}{\multicolumn{2}{|c|}{$\begin{array}{l}0.1140 \\
0.3979 \\
0.1048\end{array}$}} & \multirow{3}{*}{\multicolumn{2}{|c|}{$\begin{array}{l}0.0268 \\
0.0934 \\
0.0202\end{array}$}} & \multirow{3}{*}{\multicolumn{2}{|c|}{$\begin{array}{l}0.00819 \\
0.0286 \\
0.00794\end{array}$}} & \multirow{3}{*}{\multicolumn{2}{|c|}{$\begin{array}{l}0.0153 \\
0.0533 \\
0.00577\end{array}$}} \\
\hline & sphere(hazy) & & & & & & & & & & \\
\hline & stratosphere & & & & & & & & & & \\
\hline
\end{tabular}



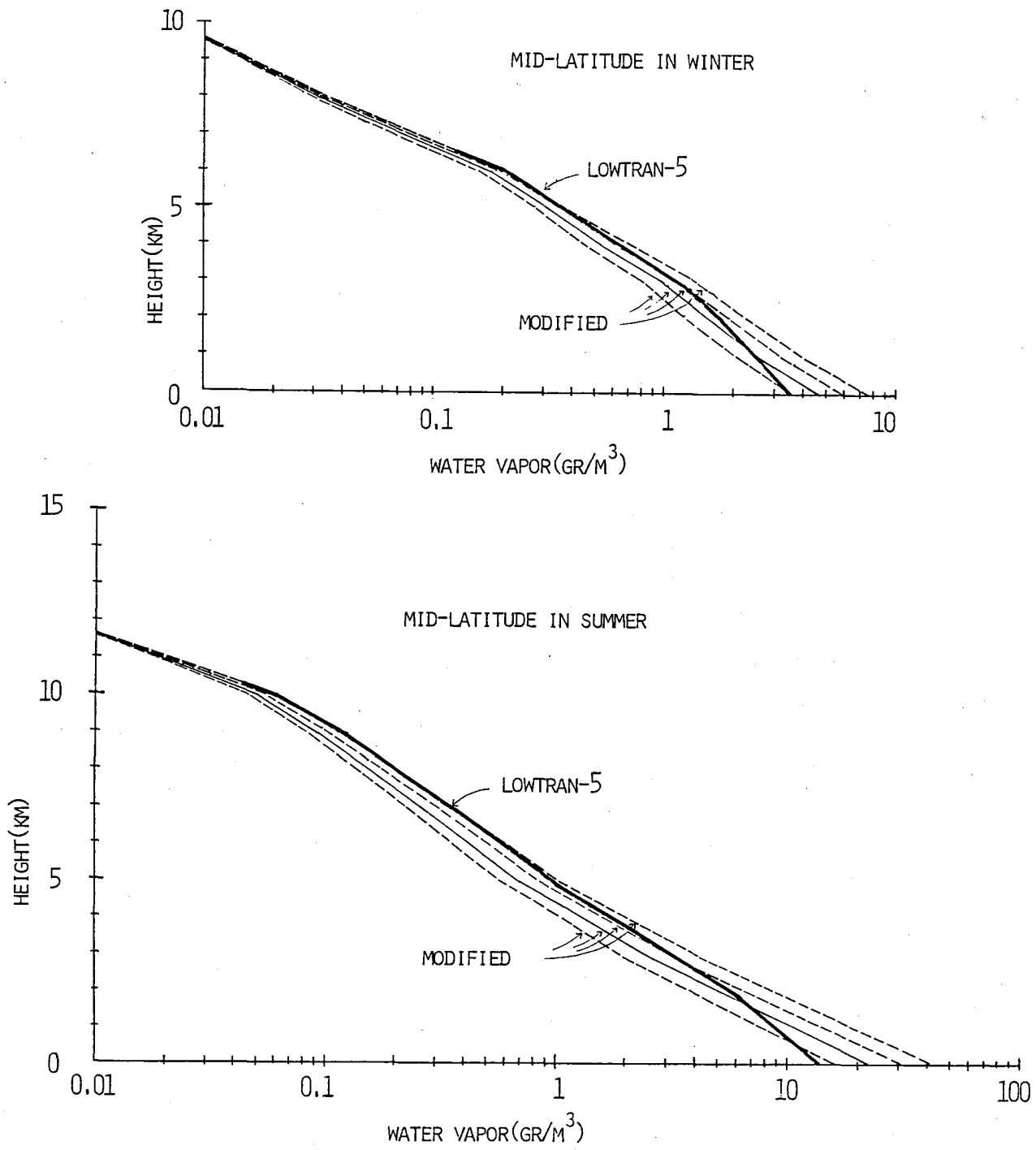

Fig. 1 Vertical profiles of the modified water vapor concentration in mid-latitudes in summer and in winter. LOWTRAN-5 distribution is also shown.

Secondly the diffusely reflected radiation and the emitted radiation from the model atmosphere-ocean system at top are computed by using the adding method (Takashima et al., 1977). Thirdly a comparison of the brightness temperature measured from space with the model computations is undertaken to find the most appropriate atmospheric parameters with the aid of the graphical expressions of these parameters that could correct SST referred to. Finally SST thus determined is compared with that reported by ships. The present work is the extension of the previous paper (Takashima and Takayama, 1983), where the stratospheric aerosols were not considered.

\section{Results and discussions}

(1) model computations

One of the most important gases to affect SST is water vapor which unfortuntely varies in time and space. Thus for an accurate correction of water vapor, the vertical profile of its concentration must be simultaneously known. Let us consider a vertical profile of 
water vapor concentration which is modified to be more or less in the lower troposphere than that of Lowtran-5 distribution. This modification decreases with altitude exponentially, becoming at the tropopause. The computational results for observetion angle $(\theta) 14.4^{\circ}$ show that the temperature correction ranges from 2.2 to $4.6 \mathrm{~K}$ due to water vapor in the atmosphere at ch. 4 , whereas it is up to $0.2 \mathrm{~K}$ for the tropospheric aerosols. It is $0.4 \mathrm{~K}$ or $1 \mathrm{~K}$ for $\tau^{\mathrm{s}}=0.1$ or 0.3 , respectively, for the stratospheric aerosols, where the optical thickness is assumed to be 0.1 or 0.3 , respectively, at a wavelength $0.55 \mu \mathrm{m}$. Here the problem is how much the brightness temperature observed from space should be corrected to drive SST accurately. The brightness temperature changes $0.8 \mathrm{~K}$ for the difference between ch. 4 and ch. 5 when the total amount of water vapor changes from 2.26 to $5.24 \mathrm{gr} / \mathrm{cm}^{2}$ in mid-latitudes in summer, whereas the change of the tropospheric aerosols from clear to hazy conditions affects only $0.04 \mathrm{~K}$ on SST and the presence of the stratospheric aerosols does about $0.1 \mathrm{~K}$ for $\tau^{\mathrm{s}}=$ 0.1 . Thus the effect of atmospheric aerosols on SST is much less than that of water vapor for the temperature difference between ch. 4 and ch. 5 . However the effect of aerosols could not be distinguished from the effect of water vapor on SST. The temperature difference between ch. 3 and ch. 4 ranges $1.9 \mathrm{~K}$ for the same change of water vapor amount. The dependence of the temperature difference on the change of water vapor amount is more than that for the difference between ch. 4 and ch. $5(\Delta \mathrm{T}=0.8 \mathrm{~K})$. The effect of the tropospheric aerosols is about $0.2 \mathrm{~K}$ and that of the stratospheric aerosols is about $0.07 \mathrm{~K}$ or less for $\tau^{\mathrm{s}}=0.1$.

The magnitude of atmospheric correction on SST increases with the increase of nadir angle of observation. For $\theta=53.1^{\circ}$, the temperature correction due to water vapor counts for from 3 to $6 \mathrm{~K}$ at ch. 4 , whereas it does from $0.1 \mathrm{~K}$ to $0.3 \mathrm{~K}$ for the tropospheric aerosols. As

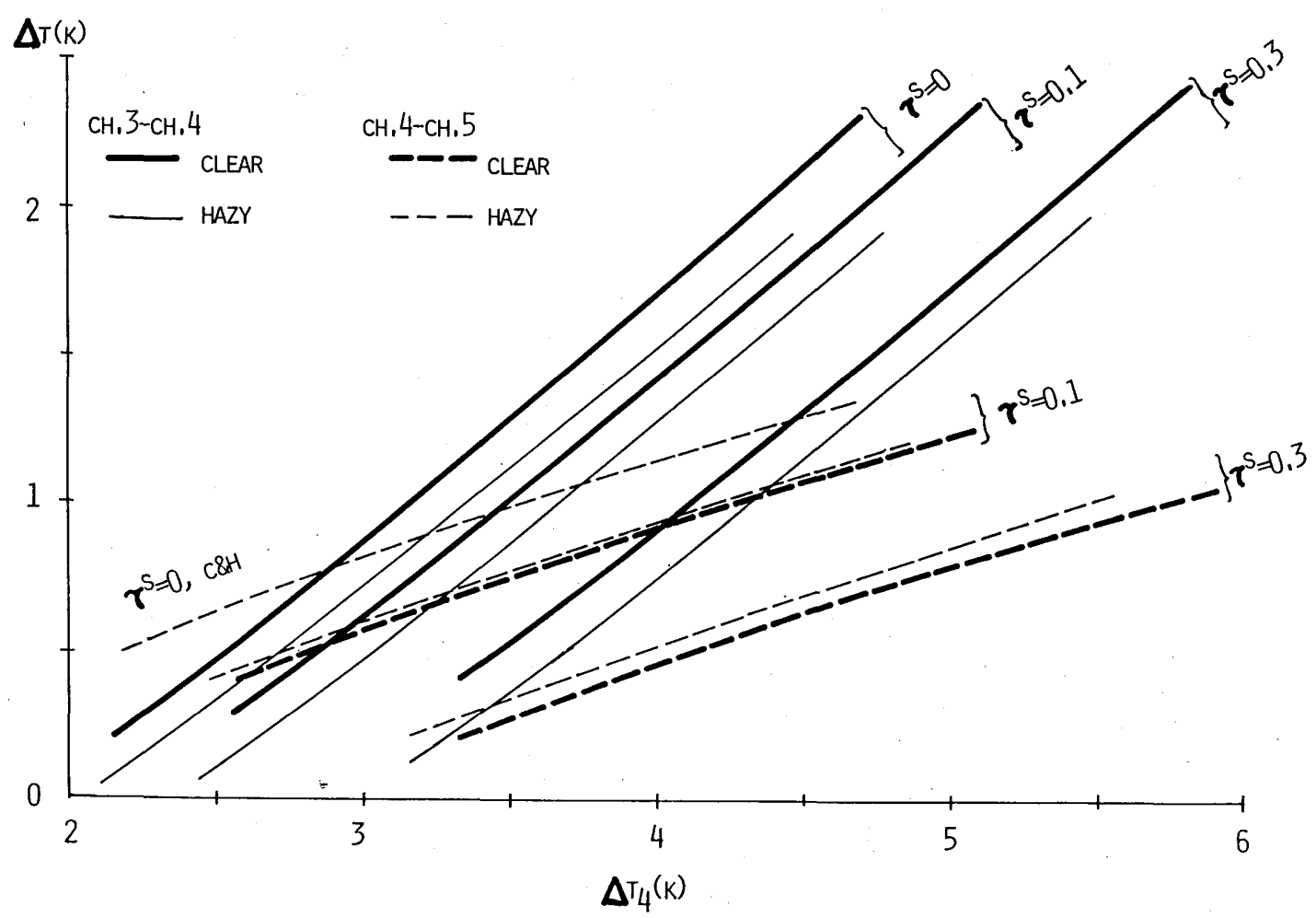

Fig. 2a Temperature difference versus corection on the brightness temprerature in the mid-latitudes in summer at channel 4 for $\theta=14.4^{\circ}$. Optical thickness of stratospheric aerosols $\left(\tau^{\mathrm{s}}\right)$ is normalized to 0.1 or 0.3 at $0.55 \mathrm{~m}$. 
for the stratospheric aerosols, it counts for 0.6 $\mathrm{K}$ and $2 \mathrm{~K}$ for $\tau^{\mathrm{s}}=0.1$ and 0.3 , respectively.

Fig. 2a shows the temperature difference $(\Delta \mathrm{T})$ among channels 3,4 and 5 versus expected temperature correction $\left(\Delta \mathrm{T}_{4}\right)$ on the brightness temperature observed from space at channel 4 for $\theta=14.4^{\circ}$. This is applicable to mid-latitudes in summer. Suppose that $\Delta \mathrm{T}_{3-4}$ is $1 \mathrm{~K}$, then $\Delta \mathrm{T}_{4}$ becomes $3.16 \mathrm{~K}$ and $3.35 \mathrm{~K}$ for the clear and hazy, atmospheric conditions, respectively, without stratospheric aerosols, whereas $\Delta \mathrm{T}_{4}$ becomes $3.48 \mathrm{~K}$ and $3.68 \mathrm{~K}$, respectively, with $\tau^{\mathrm{s}}=0.1$. Similarly suppose that $\Delta \mathrm{T}_{3-4}$ is $0.96 \mathrm{~K}$, then $\Delta \mathrm{T}_{4}$ becomes $3.16 \mathrm{~K}$ for clear and hazy conditions without stratospheric aerosols. $\Delta \mathrm{T}_{4}$ becomes 3.85 and $3.87 \mathrm{~K}$, respectively, with $\tau^{\mathrm{s}}=$ 0.1. The stratospheric aerosols affect $\Delta \mathrm{T}_{4-5}$ more, whereas the tropospheric aerosols do $\Delta \mathrm{T}_{3-4}$ more. Thus there is no way to correct the effect of the atmospheric aerosols. It counts up to $0.4 \mathrm{~K}$ on $\Delta \mathrm{T}_{4}$ derived by $\Delta \mathrm{T}_{3-4}$, including the effect of the stratospheric aerosols $(0.2 \mathrm{~K})$.

So far the vertical profiles of water vapor concentration has been modified in such a way that the concentration in the troposphere changes with altitude exponentially.
If a vertical profile is modified in such a way that the concentration is less in the middle troposphere (Fig. 1), the temperature difference $\left(\Delta \mathrm{T}_{4}\right)$ for the change of vertical distribution of water vapor becomes $0.07 \mathrm{~K}$ and $0.8-0.9 \mathrm{~K}$ with the change of $\Delta \mathrm{T}_{3-4}, 1 \mathrm{~K}$ and $2 \mathrm{~K}$, respectively for $\theta=14.4^{\circ}$, whereas that on $\Delta T_{4}$ becomes 0.2 $\mathrm{K}$ and $0.5 \mathrm{~K}$ with the change of $\Delta \mathrm{T}_{4-5}, 0.5 \mathrm{~K}$ and $1.0 \mathrm{~K}$, respectively. Thus the dependence of $\Delta \mathrm{T}$ on the vertical profile of water vapor concentration is less at channel 3 , but is greater at channel 5. Unfortunately the present method of deriving SST based on the temperature differences among three channels, 3, 4 and 5 dose not cover the dependence of SST on the vertical profile of water vapor concentration. The errors count for about $0.1 \mathrm{~K}$ and $0.5 \mathrm{~K}$ for $\Delta T_{3-4}$ and $\Delta T_{4-5}$, respectively, for the present two model distributions in mid-latitudes in summer.

(2) Comparison of ship data with satellitederived SST at night

Fig. 3 shows the comparison of SST reported by ships with the satellite-derived SST along $19 \mathrm{~N}$ (130-160 E) at 2 am (JST) on June 9, 1982. Data of each pixels are marked. The

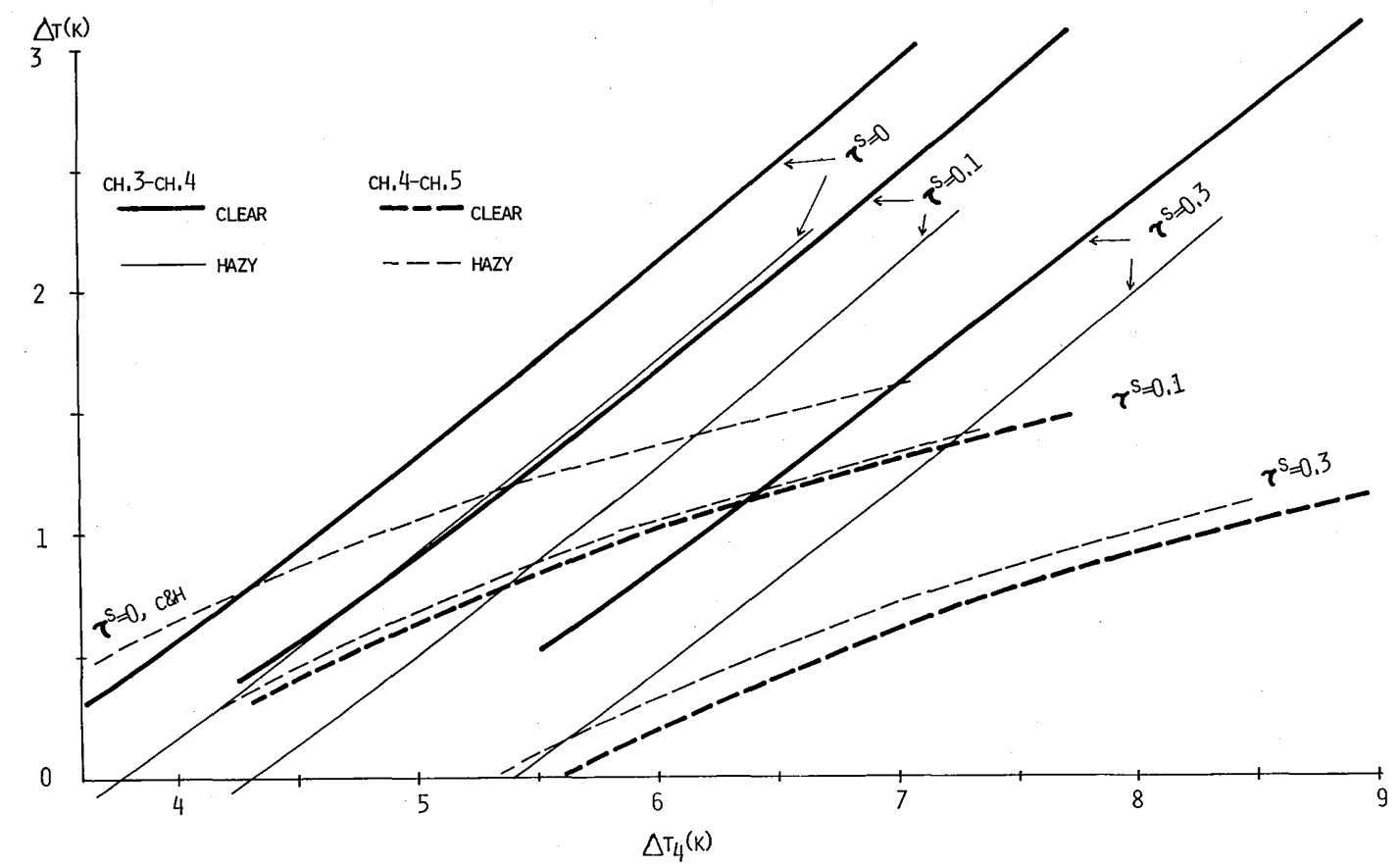

Fig. 2b The same as Fig. 2a, but for $\theta=53.1^{\circ}$. 

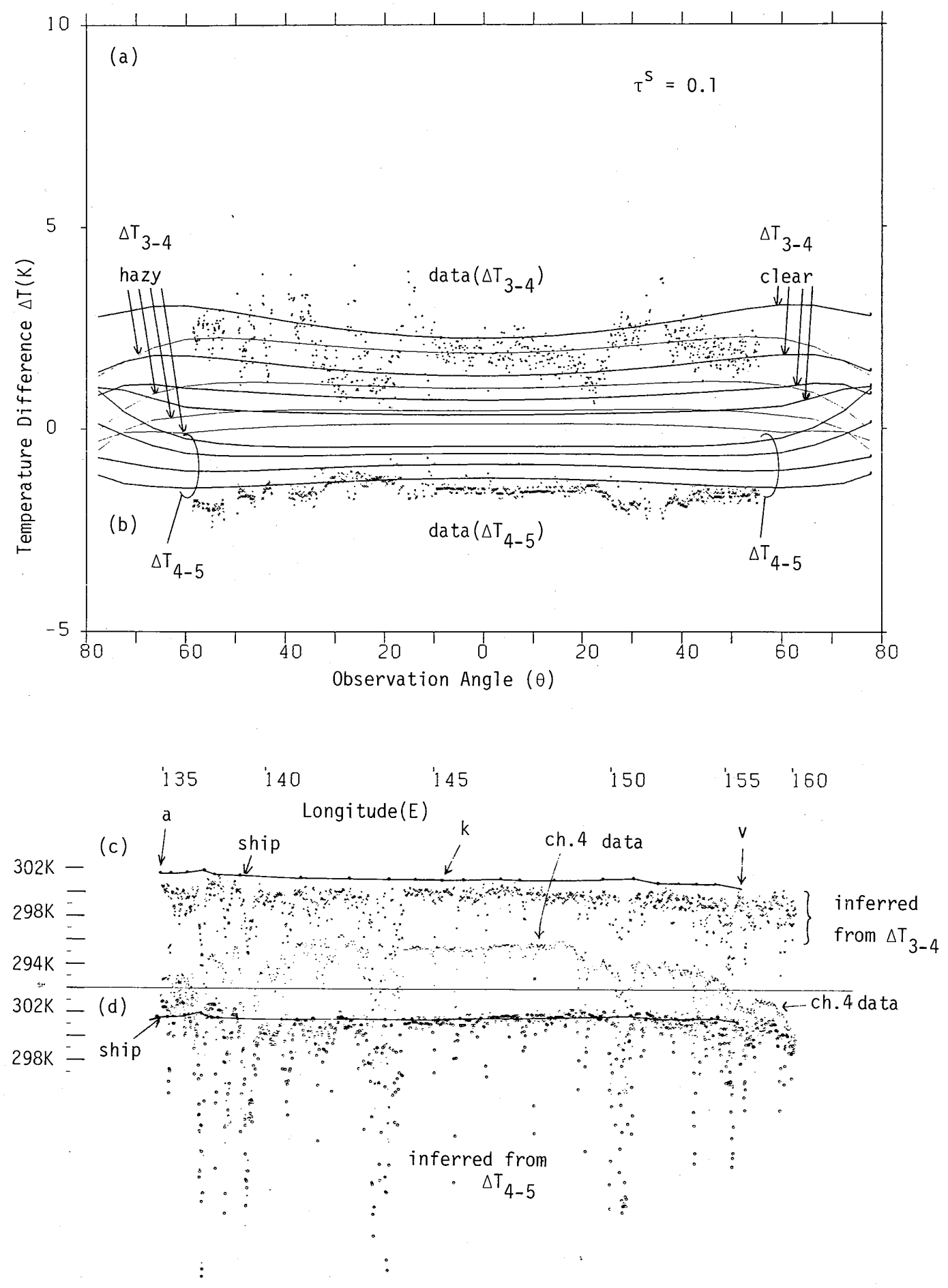

Fig. 3 Comparison of ship data with the satellite derived SST on June 9, 1982 over the area $\left(19^{\circ} \mathrm{N}, 130-160^{\circ} \mathrm{E}\right)$ 


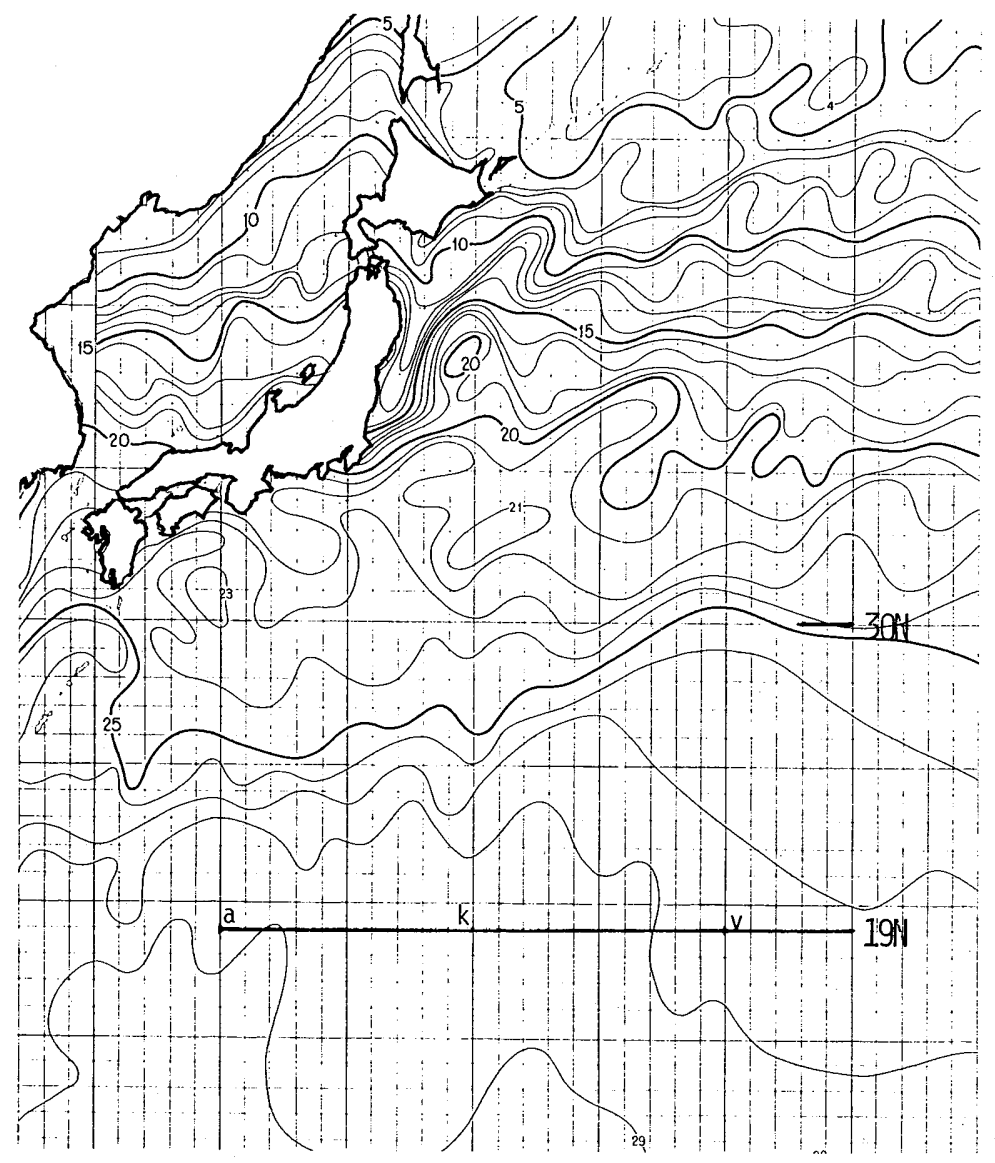

Fig. 4 Mean sea surface temperature by ships (June 1-10, 1982).

mean sea-surface temperature in the period from June 1 to June 10, 1982, and the scan line of the satellite are shown in Fig. 4. In the analysis, the optical thickness of the stratospheric aerosols is assumed to be 0.1 at wavelength $0.55 \mu \mathrm{m}$. Part (a) in Fig. 3 shows the corresponding temperature difference $\left(\Delta \mathrm{T}_{3-4}\right)$ between ch. 3 and ch. 4 . The abscissa shows the nadir angle of observations and the corresponding longitude. The heavy lines indicate the computational results of the model atmosphere (clear) with the modified water vapor content of $2.42,3.24,4.34$ and $5.81 \mathrm{gr} / \mathrm{cm}^{2}$ from the top to the bottom lines, respectively, for mid-latitudes in summer. The corresponding temperature differences due to the hazy atmosphere are shown by fine lines. There is no way to derive the atmospheric condition clear or hazy simultaneously with these three channels. Part (b) is the same as part (a), but for the temperature difference $\left(\Delta T_{4-5}\right)$ between ch. 4 and ch. 5 . The top line corresponds to the atmosphere with water vapor content of $2.42 \mathrm{gr} / \mathrm{cm}^{2}$, the bottom one to that of $5.81 \mathrm{gr} / \mathrm{cm}^{2}$. Within the zenith angle of $40^{\circ}, \Delta \mathrm{T}$ shows very little dependence on nadir angles of observations numerically. In part (a), observed satellite data distribute mostly within water vapor content from 3.24 to $5.81 \mathrm{gr} / \mathrm{cm}^{2}$, with the exception of the cloudy areas, whereas in part (b), $\Delta \mathrm{T}_{4-5}$ indicates the amount mostly over $5.81 \mathrm{gr} / \mathrm{cm}^{2}$. As a result, to obtain SST the extrapolation technique has to be employed. Unfortunately $\Delta T_{4-5}$ is almost saturated with the further increase of water vapor content. Thus the derived water vapor content with $\Delta \mathrm{T}_{4-5}$ is different from that with $\Delta \mathrm{T}_{3-4}$. This discrepancy may be mainly due to the model atmosphere-ocean system. It should 
be noted that the derived SST with $\Delta \mathrm{T}_{3-4}$ was in good agreement with that of $\Delta \mathrm{T}_{4-5}$ on the same day along the longitude at $27^{\circ} \mathrm{N}$ where this area may be out of the influence of stratospheric aerosols (Takashima and Takayama, 1983). The present case with $\tau^{\mathrm{s}}=0$. 3 appears not to be a better simulation of SST either. This may be due to the dense water vapor at latitude $19^{\circ} \mathrm{N}$, information on the vertical profiles of water vapor concentration and temperature is also needed. The SST's derived from $\Delta \mathrm{T}_{3-4}$ are shown in part (c). Their averages are lower as much as $1.5 \mathrm{~K}$ in comparison with those reported by ships, whereas those from $\Delta \mathrm{T}_{4-5}$ in part (d) are $0.52 \mathrm{~K}$ lower than those by ships. The corresponding results without stratospheric aerosols are $1.93 \mathrm{~K}$ and $0.66 \mathrm{~K}$, respectively. The results are better for the model in which the stratspheric aerosols are included. The SST's derived from space for

Table 2 Comparison of SST derived from space with that of ship data along latitude $19^{\circ} \mathrm{N}$. Alphabetic symbols a, b, $\cdots$, v represent locations along $\lambda=19^{\circ} \mathrm{N} . \quad \phi=$ longitude, $\theta=$ zenith, $T_{\text {ship }}=$ temperature by ship, $T_{3,4}=$ SST from chs. $3 \& 4 . \Delta T=T_{3,4}\left(T_{4,5}\right)-T_{\text {ship }}, \tau^{s}=$ optical thickness of stratospheric aerosols at $0.55 \mu \mathrm{m}$.

\begin{tabular}{|c|c|c|c|c|c|c|c|c|c|c|c|}
\hline & \multirow{2}{*}{$\phi$} & \multirow{2}{*}{$\theta$} & \multirow{2}{*}{$T_{\text {ship }}$} & \multicolumn{4}{|c|}{$\tau^{s}=0$} & \multicolumn{4}{|c|}{$\tau^{s}=0.1$} \\
\hline & & & & $T_{3,4}$ & $\Delta T$ & $T_{4,5}$ & $\Delta T$ & $T_{3,4}$ & $\Delta T$ & $T_{4,5}$ & $\Delta T$ \\
\hline a & 135.30 & 57.60 & 28.7 & 26.46 & -2.24 & 28.35 & -0.35 & 27.08 & -1.62 & 29.72 & 1.02 \\
\hline b & 136.0 & 55.31 & 28.8 & 25.97 & -2.83 & 28.09 & -0.71 & 26.55 & -2.25 & 29.39 & 0.59 \\
\hline c & 136.50 & 53.40 & 28.9 & 26.18 & -2.72 & 28.24 & -0.66 & 26.73 & -2.17 & 29.47 & 0.57 \\
\hline d & 137.04 & 51.46 & 28.9 & 26.36 & -2.54 & 27.34 & -1.56 & 26.72 & -2.18 & 27.27 & -1.63 \\
\hline e & 137.90 & 47.94 & 28.9 & 27.02 & -1.88 & 28.42 & -0.48 & 27.52 & -1.38 & 29.53 & 0.63 \\
\hline $\mathrm{f}$ & 138.80 & 43.80 & 28.6 & 26.93 & -1.67 & 28.11 & -0.49 & 27.38 & -1.22 & 29.13 & 0.53 \\
\hline$g$ & 141.10 & 31.35 & 28.4 & 26.23 & -2.17 & 27.42 & -0.98 & 26.60 & -1.80 & 28.27 & -0.13 \\
\hline h & 142.06 & 25.52 & 28.3 & 26.57 & -1.73 & 27.22 & -1.08 & 26.92 & -1.38 & 28.02 & -0.28 \\
\hline $\mathrm{i}$ & 142.90 & 19.77 & 28.3 & 26.22 & -2.08 & 27.78 & -0.52 & 26.56 & -1.74 & 28.54 & 0.24 \\
\hline$j$ & 143.94 & 12.15 & 28.3 & 26.79 & -1.51 & 27.11 & -1.19 & 27.12 & -1.18 & 27.83 & -0.47 \\
\hline $\mathrm{k}$ & 145.11 & 3.10 & 28.3 & 26.57 & -1.73 & 27.42 & -0.88 & 26.89 & -1.41 & 28.13 & -0.17 \\
\hline 1 & 145.98 & 3.65 & 28.3 & 26.91 & -1.39 & 27.62 & -0.68 & 27.23 & -1.07 & 28.33 & 0.03 \\
\hline $\mathrm{m}$ & 146.96 & 11.16 & 28.3 & 26.94 & -1.36 & 27.57 & -0.73 & 27.26 & -1.04 & 28.29 & -0.01 \\
\hline $\mathrm{n}$ & 148.01 & 18.89 & 28.3 & 26.34 & -1.96 & 28.01 & -0.29 & 26.67 & -1.63 & 28.76 & 0.46 \\
\hline o & 148.95 & 25.33 & 28.3 & 26.51 & -1.79 & 28.04 & -0.26 & 26.87 & -1.43 & 28.83 & 0.53 \\
\hline $\mathrm{p}$ & 149.98 & 31.74 & 28.3 & 26.28 & -2.02 & 27.64 & -0.66 & 26.66 & -1.64 & 28.48 & 0.18 \\
\hline$q$ & 150.99 & 37.48 & 28.2 & 26.35 & -1.85 & 27.97 & -0.23 & 26.76 & -1.44 & 28.88 & 0.68 \\
\hline $\mathrm{r}$ & 152.08 & 42.97 & 28.0 & 26.81 & -1.19 & 27.41 & -0.59 & 27.26 & -0.74 & 28.42 & 0.42 \\
\hline $\mathrm{s}$ & 153.02 & 47.18 & 27.8 & 25.56 & -2.24 & 27.30 & -0.50 & 26.62 & -1.18 & 28.40 & 0.60 \\
\hline $\mathrm{t}$ & 153.86 & 50.60 & 27.6 & 25.94 & -1.66 & 27.50 & -0.10 & 26.46 & -1.14 & 28.67 & 1.07 \\
\hline $\mathrm{u}$ & 155.01 & 54.79 & 27.6 & 25.77 & -1.83 & 26.91 & -0.69 & 26.34 & -1.26 & 28.19 & 0.59 \\
\hline $\mathrm{v}$ & 155.97 & 57.88 & 27.4 & 25.28 & -2.12 & 26.56 & -0.84 & 25.90 & -1.50 & 27.94 & 0.54 \\
\hline & & $\Sigma \mid \Delta T$ & $1 / N$ & & 1.932 & & 0.658 & & 1.473 & & 0.517 \\
\hline
\end{tabular}


different locations along $19^{\circ} \mathrm{N}$ are shown in Table 2.

(3) Comparison of ship data with SST from space in the daytime

Fig. 5 shows the infrared data of AVHRR over the same area as shown in Fig. 3 at $1 \mathrm{pm}$ (JST) on June 9, 1982. These data in the daytime orbit were taken 11 hours after the night obit. A high temperature is observed on the lefthand side of $\mathrm{ch}$. 3 , which is due to the solar radiation directly reflected by the ocean surface. Therefore the surface state is essential to derive SST from the upwelling radiation, whereas it slightly depends on the atmospheric parameters. Part (a) in Fig. 5 shows the corresponding temperature difference between ch. 3 and ch. 4 . The dots indicate the AVHRR data, where the solar zenith angle ranges from $34^{\circ}$ to $44^{\circ}$. At the center of the sunglint, the solar zenith angle is about $28^{\circ}$. The azimuth between the anti-solar and the satellite directions ranges from $162^{\circ}$ to $168^{\circ}$ on the right of Fig. 5. The case of the solar zenith angle of $30.4^{\circ}$ and their azimuth of $10^{\circ}$ is shown, where the surface wind is $5 \mathrm{~m} / \mathrm{sec}$. Computational results show that $\Delta \mathrm{T}_{3-4}$ dose not depend upon surface wind and solar zenith in the region off the sunglint. Thus off the sunglint, $\Delta \mathrm{T}$ depends upon the total amount of water vapor and aerosols in a manner similar to the night case. Part (b) shows the same as part (b) $\left(\Delta \mathrm{T}_{4-5}\right)$, but for the daytime. Off the sunglit, the SST's derived from $\Delta \mathrm{T}_{3-4}$ and $\Delta \mathrm{T}_{4-5}$ are shown in parts (c) and (d), respectively. Their trends are noted to be the same as those of parts (c) ald (d) in Fig. 3. Table 3 shows the comparison of ship data with the satellite-derived SST in the daytime The atmospheric condition was assumed to be clear with the aid of a visibility of $20 \mathrm{~km}$ and a surface wind of $5 \mathrm{~m} / \mathrm{sec}$ reported by ships.

(4) Comparison of the AVHRR with the model computations in channels 1 and 2 .

Since the AVHRR data in the visible channels 1 and 2 are not calibrated after its launching, the data might have errors to some extent. However, these visible channels contain a lot of useful information with respect to aerosols and water vapor. Such information may permit the quantitative analysis of data in infrared. Fig. 6 shows albedo difference between ch. 1 and ch. 2 of AVHRR (marked by dots), using the same data as in Fig. 5. The top lines in clear and hazy conditions correspond to the case of water vapor content $5.81 \mathrm{gr} / \mathrm{cm}^{2}$, whereas the bottom lines to the case of $2.42 \mathrm{gr} /$ $\mathrm{cm}^{2}$. By the present computations, the zenith and the azimuth of the incident solar radiation are $30.4^{\circ}$ and $10^{\circ}$, respectively. The surface wind is $5 \mathrm{~m} / \mathrm{sec}$. Off she sunglint, the present results under the clear condition simulates those of AVHRR data well. The effect of water vapor does not show any appreciable difference on albedo difference under the clear condition. These results agree with the visibility reported by ships. In the sunglint, under the hazy condition, albeda difference changes monotonically with an increase of zenith angle of observations, whereas under the clear condition, it shows the peak values in the sunglint. The present computations are slightly higher than those of AVHRR data. This might be partly due to the fact that in the present simulation, the atmosphere is assumed to be clear under a wind speed of $5 \mathrm{~m} / \mathrm{sec}$. With less wind speed or a smaller amount of aerosols in the atmosphere by keeping the other parameters unchanged (water vapor content is 2.42 $\mathrm{gr} / \mathrm{cm}^{2}$ ), better results could be expected. Off the sunglint albedo difference of the case of $\tau^{\mathrm{s}}=0$ does not show any appreciable difference from that of $\tau^{\mathrm{s}}=0.1$. In the sunglint albedo difference with $\tau^{\mathrm{s}}=0.1$ is slightly lower than those without stratospheric aerosols in clear condition, whereas in hazy condition they are slightly higher. Thus the present study provides us information on the tropospheric aerosols.

\section{Conclusion}

We have discussed in the above a method of deriving the sea surface temperature by using the five channels of AVHRR on board NOAA-7 in the region from visible to infrared, where a little information with respect to the aerosols was obtained in the visible channels. In the present data the atmosphere may be contaminated by the stratospheric aerosols due to E1 Chichon eruption. Hitherto the case of the present area has been studied without considering the influence of the strotospheric aerosols. These studies suggest that the effect 


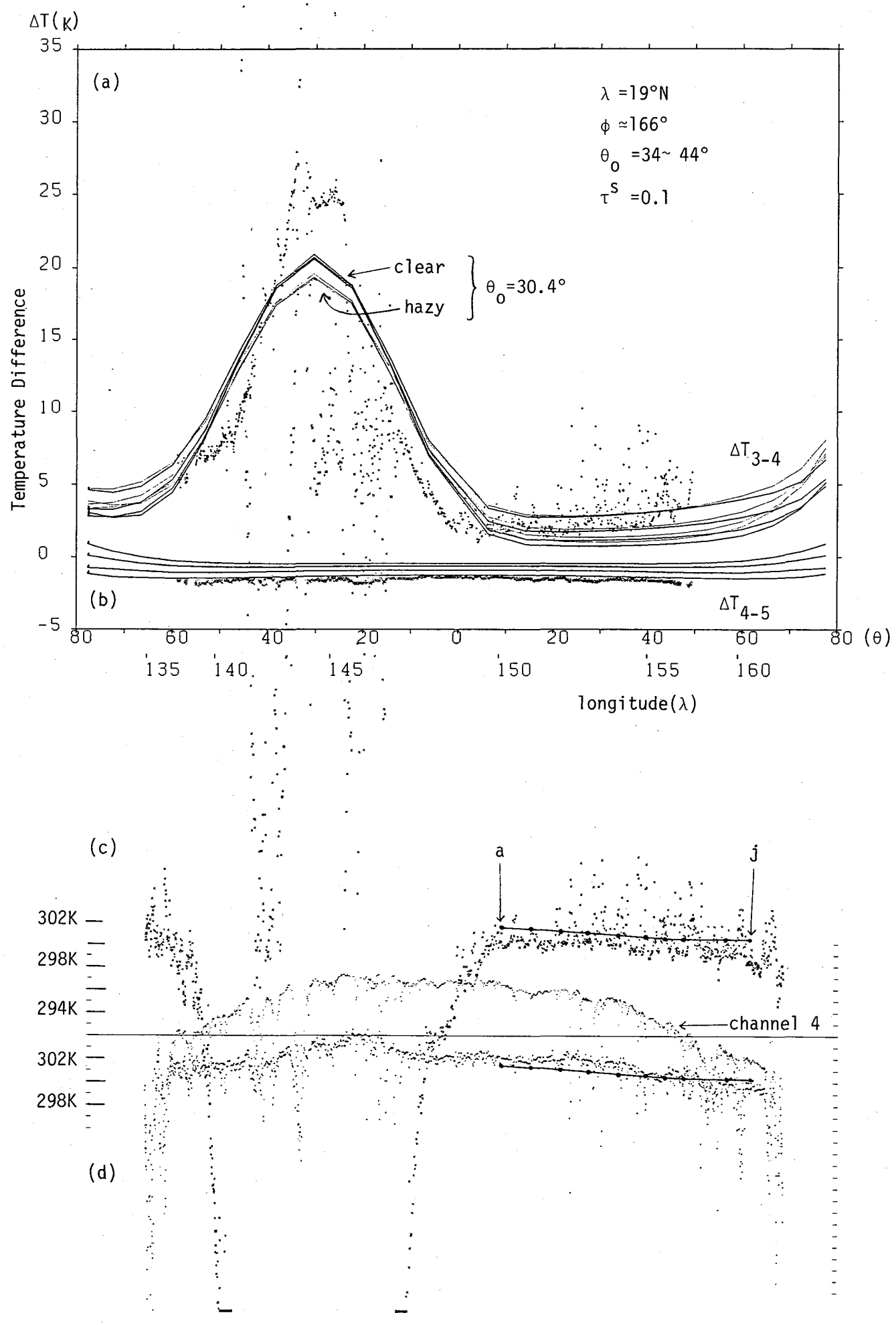

Fig. 5 The same as Fig. 3, but for the daytime. 
Table 3 The same as Table 2 , but for the daytime. $\theta_{0}=$ solar zenith, $\phi=$ azimuth between solar and observation directions.

\begin{tabular}{|c|c|c|c|c|c|c|c|c|c|c|c|c|c|}
\hline & \multirow{2}{*}{$\lambda$} & \multirow{2}{*}{$\theta_{0}$} & \multirow{2}{*}{$\theta$} & \multirow{2}{*}{$\phi$} & \multirow{2}{*}{$T_{\text {ship }}$} & \multicolumn{4}{|c|}{$\tau^{s}=0$} & \multicolumn{4}{|c|}{$\tau^{s}=0.1$} \\
\hline & & & & & & $T_{3,4}$ & $\Delta T$ & $T_{4,5}$ & $\Delta T$ & $T_{3,4}$ & $\Delta T$ & $T_{4,5}$ & $\Delta T$ \\
\hline a & 150.0 & 34.0 & 8.3 & 166.2 & 28.3 & 26.78 & -1.52 & 27.99 & -0.31 & 26.91 & -1.39 & 28.71 & 0.41 \\
\hline $\mathrm{b}$ & 151.0 & 34.9 & 15.7 & 166.3 & 28.2 & 28.09 & -0.11 & 27.53 & -0.67 & 28.23 & 0.03 & 28.26 & 0.06 \\
\hline c & 152.0 & 35.8 & 22.6 & 166.4 & 28.0 & 26.73 & -1.27 & 27.58 & -0.42 & 27.13 & -0.87 & 29.23 & 1.23 \\
\hline d & 153.0 & 36.7 & 28.5 & 166.5 & 27.8 & 26.22 & -1.58 & 27.89 & 0.09 & 26.38 & -1.42 & 28.71 & 0.91 \\
\hline e & 154.0 & 37.6 & 34.4 & 166.6 & 27.6 & 26.47 & -1.13 & 27.78 & 0.18 & 26.64 & -0.96 & 28.66 & 1.06 \\
\hline $\mathrm{f}$ & 155.0 & 38.5 & 39.7 & 166.7 & 27.6 & 27.82 & 0.22 & 25.13 & -2.47 & 27.98 & 0.38 & 26.08 & -1.52 \\
\hline $\mathrm{g}$ & 156.0 & 39.4 & 44.4 & 166.8 & 27.4 & 26.81 & -0.59 & 26.59 & -0.81 & 26.98 & -0.42 & 27.62 & 0.22 \\
\hline $\mathrm{h}$ & 157.0 & 40.3 & 49.0 & 166.9 & 27.4 & 28.29 & 0.89 & 26.37 & -1.03 & 28.45 & 1.05 & 27.50 & 0.10 \\
\hline i & 159.3 & 42.3 & 56.8 & 167.2 & 27.3 & 25.92 & -1.38 & 25.96 & -1.34 & 26.02 & -1.28 & 27.30 & 0.0 \\
\hline $\mathrm{j}$ & 161.3 & 44.1 & 62.6 & 167.4 & 27.3 & 24.83 & -2.47 & 25.52 & -1.78 & 24.83 & -2.47 & 27.07 & -0.24 \\
\hline \multicolumn{6}{|c|}{$\Sigma|\Delta T| / N$} & & 1.116 & & 0.910 & & 1.027 & & 0.575 \\
\hline
\end{tabular}

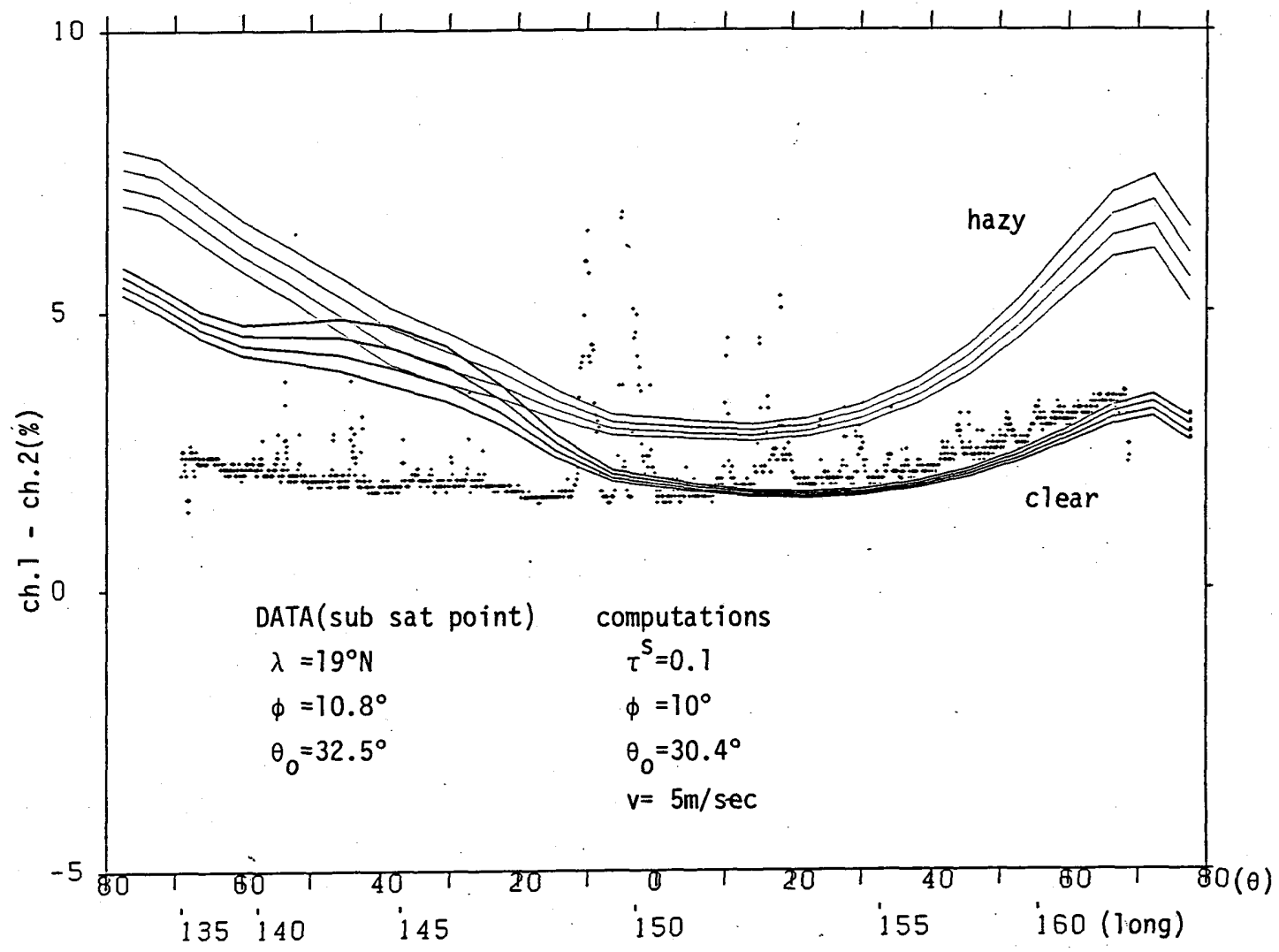

Fig. 6 Comparison of the AVHRR data with the model computations in channels 1 and 2. Albedo difference between channels 1 and 2 are shown with the change of total water vapor content from $2.42 \mathrm{gr} / \mathrm{cm}^{2}$ to $5.81 \mathrm{gr} / \mathrm{cm}^{2}$ in clear and hazy conditions. 
of stratospheric aerosols is not negligible, but a more important point is that a knowledge of the vertical profiles of water vapor and temperature are essential to derive SST accurately for the atmosphere with a dense water vapor. It has been proposed to shift the present $3.7 \mu \mathrm{m}$ wavelength region in $\mathrm{ch} .3$ to the region where the water vapor effect is much less (around 4 $\mu \mathrm{m})$. However, this would not improve the accuracy of the SST by the current choice of the $3.7 \mu \mathrm{m}$ region very much due to the same number of channels. With the present number of channels, it may be difficult to derive SST accurately, since it would not simultaneously take into account the profiles mentioned above in the investigation. Thus an extra channel of $3.7 \mu \mathrm{m}$ region would improve the accuracy of SST.

Acknowledgement: The authers owe much to K. Masuda of MRI for his useful suggestions about computations. Computations were carried out by the HITAC M200H of MRI.

\section{References}

Cox, C. and W. Munk, 1955: Some problems in optical oceanograhy, J. Mar. Res. 14, 63-78.

Deirmendjian, D., 1969: Electromagnetic Scattering on Spherical Polydispersions, Elsevier Pub. Co., $290 \mathrm{p}$.

Hale, G.M. and M.R. Querry, 1973: Optical constant of water in the $200-\mathrm{nm}$ to $200-\mu \mathrm{m}$ wavelength region, App1. Opt., 12, 555-563.

Hofmann, D. J. and J. M. Rosen, 1983: Stratospheric sulfuric acid fraction and mass estimate for the 1982 volcanic eruption of E1
Chichon, Geophys. Res. Lett., 10, 313-316.

King, M.D., Harshvardhan and Albert Arking, 1984: A model of the radiative properties of the E1 Chichon stratospheric aerosols layer, J. Climate Appl. Meteor., 23, 1121-1120.

McClatchey, R.A., R.W. Fenn, J.E.A. Selby, F.E. Volz, and J.S. Garing, 1972: Optical properties of the atmosphere (third edition). AFCRL-720497, Air Force Cambridge Research Laboratories, L.G. Hanscon Field, Bedford MA, 108pp.

Palmer Kent F. and Dudley Williams, 1975: Optical constants of sulfuric acid; Application to the cloudes of Venus?, Appl. Opt., 14, 208-219.

Prabhakara, C., G. Dalu, and V.G. Kunde, 1974: Estimation of sea surface temperature from remote sensing in the 11 - to $13 \mu \mathrm{m}$ window region, J. Geophy. Res., 79, 5039-5044.

Selby, J.E.A., F.X. Kneizys, J.H. Chetwynd, Jr., and R.A McClatchey, 1978: Atmospheric transmittance/radiance: Computer code LOWTRAN 4, AFGL-TR-78-0053, Air Force Geophysics Laboratory, Hanscom AFB, Bedford, MA, 100pp.

Strong Alan E., L.L. Stowe and C.C.Walton, 1983 : Using the NOAA-7 AVHRR data to monitor E1 Chichon aerosol evolution and subsequent ocean surface temperatures anomalies, 17-th International Sym. Remote Sensing Environment, Ann Arbor, Michigan, May 9-13, 107-122.

Takashima, T., C.I. Taggart and E.G. Morrissey, 1977: A method of computing the emergent radiation by the atmosphere in the region ranging from ultra-violet to infrared radiation, Astrophys. Space Sci., 49, 331-337.

Takashima, T. and Y. Takayama, 1983: Investigation of the atmospheric aerosols and water vapor by the AVHRR radiometer (visible and IR) on board NOAA-7, Fifth Conf. Atm. Radiation, Baltimore, 90-93.

\title{
成層圏エーロゾルの影響を考慮した海面温度測定
}

\author{
高島 勉・高山 陽三 \\ 大気一海洋系モデルによる放射輝度計算結果と NOAA 7 号衛星搭載の AVHRR 放射計の赤外チャンネルに \\ よるデータの比較から, 成層圈エーロゾルの影響のない場合で, 水蒸気量が適量の時, チャンネル $3,4,5$ のデー \\ 夕から精度良く海面温度が求まる事がわかった。しかし水蒸気量の多い場合, 成層圈エーロゾルの影響のある場 \\ 合についてはこれら 3 チャンネルのみの利用では不充分で，可視域のデー夕の同時利用を試みた。
}

